\title{
Chromosome assignment of two cloned DNA probes hybridizing predominantly to human sex chromosomes
}

\author{
Gudrun A. Rappold ${ }^{1}$, T. Cremer ${ }^{1}$, C. Cremer ${ }^{2}$, W. Back ${ }^{1}$, J. Bogenberger ${ }^{3}$, and H. J. Cooke ${ }^{4}$ \\ ${ }^{1}$ Institut für Anthropologie und Humangenetik, Universität Heidelberg, Im Neuenheimer Feld 328, D-6900 Heidelberg, \\ Federal Republic of Germany \\ ${ }^{2}$ Institut für Angewandte Physik, Universität Heidelberg, Albert-Überle-Str. 3-5, D-6900 Heidelberg, Federal Republic of Germany \\ ${ }^{3}$ Institut für Physiologische Chemie, Universität München, Schillerstr. 42, D-8000 München 2, Federal Republic of Germany \\ ${ }^{4}$ MRC Mammalian Genome Unit, Department of Zoology, University of Edinburgh, West Mains Road, GB-Edinburgh, EH 93JT
}

Summary. In situ hybridization experiments were carried out with two clones, YACG 35 and 2.8, which had been selected from two genomic libraries strongly enriched for the human $\mathrm{Y}$ chromosome. Besides the human $\mathrm{Y}$ chromosome, both sequences strongly hybridized to the human $\mathrm{X}$ chromosome, with few minor binding sites on autosomes. In particular, on the $\mathrm{X}$ chromosome DNA from clone YACG 35 hybridized to the centromeric region and the distal part of the short arm (Xp2.2). On the $Y$ chromosome, the sequence was assigned to one site situated in the border region between Yq1.1 and Yq1.2. DNA from clone 2.8 also hybridized to the centromeric region of the $\mathrm{X}$ and the distal part of the short $\operatorname{arm}(\mathrm{Xp} 2.2)$. On the $\mathrm{Y}$, however, two binding sites were observed (Yp1.1 and Yq1.2). The findings indicate that sex chromosomal sequences may be localized in homologous regions (as suggested from meiotic pairing) but also at ectopic sites.

\section{Introduction}

In the prophase of male meiosis of man, pairing occurs between the short arm of the $\mathrm{Y}$ and the distal part of the short arm of the X chromosome (Burgoyne 1982; Polani 1982; Solari 1980; Solari and Tres 1970; Moses 1975; Pearson 1970). In analogy to meiotic pairing of autosomes, these observations suggest a homology also on the level of DNA. Such a homology is supported by speculations (Haldane 1936; de la Chapelle et al. 1981; Polani 1982; Burgoyne 1982) that cross-over does occur between homologous segments of $\mathrm{X}$ and $\mathrm{Y}$.

If such cross-over events take place frequently, the DNA sequences within this region will be inherited in a pseudoautosomal mode (Burgoyne 1982). A simple calculation of the amount of DNA available at the tip of Yp distal to the crossover shows that dozens of pseudoautosomal genes might be located within this section of the $\mathrm{Y}$.

A number of experimental findings (de la Chapelle 1981; Goodfellow and Tipett 1981; Goodfellow et al. 1983) fit well to the hypothesis that on the molecular level a partial X-Y homology does indeed exist. So far, however, only a few investigations have been performed in which DNA sequences were directly compared with each other (Daiger et al. 1982; Page et al. 1982). In these studies, two $X-Y$ homologous sequences were characterized; the position of these fragments, however, on $\mathrm{X}$ and $\mathrm{Y}$ was not determined.

Offprint requests to: G. A. Rappold
In this paper, we report on the chromosomal localization of two cloned sequences, which had been selected by Benton and Davis Screening (1977) from two genomic libraries strongly enriched for the human Y chromosome (Müller et al. 1983; Cooke et al. 1983). We show that these two clones hybridize to homologous sequences present on both the human $\mathrm{X}$ and $\mathrm{Y}$ chromosome. Using in situ hybridization, an assignment to subregions of the human sex chromosomes was made. The implication of our findings to present models of $\mathrm{X}-\mathrm{Y}$ homologous regions is discussed.

\section{Material and methods}

Cell types. Cultures of human fibroblasts and of PHA-stimulated lymphocytes were used which had been derived from a patient with a normal karyotype $46, X Y$.

In addition, a Chinese hamster $\times$ human hybrid line $(\mathrm{CH}$ Y-VII) was used which had retained the $Y$ as the only free human chromosome. The karyotype of this line has been described in detail elsewhere (Cremer et al. 1982). The Y chromosome was in all cases of normal length and showed a normal G-banding pattern; no pericentric inversion was observed.

Furthermore, hybridization experiments were also performed with a mouse $\times$ man hybrid cell line ["445 $\times 393$ "] kindly provided by Dr. H. H. Ropers. This line, besides several human chromosomes $(1,3,7,12,13,18,20)$, contains a human $\mathrm{X}-\mathrm{Y}$ translocation chromosome (Xqter $\rightarrow$ Xp 22.2:: Yq11 $\rightarrow$ Yqter). In quinacrin-stained metaphase spreads, this chromosome was easily identified due to the brilliant fluorescence on Yq12 (Zech 1969).

Chromosome preparations. Metaphase chromosomes were prepared from cultured fibroblasts, lymphocytes and somatic cell hybrids, using standard procedures. Prophase chromosomes of human male peripheral lymphocytes were kindly donated by Dr. W. Schempp. For chromosome preparation the procedure described by Müller and Schempp (1982) was used except that spreading was performed by air drying.

$D N A$ probes. For in situ hybridization experiments ${ }^{3} \mathrm{H}$-nicktranslated DNA from two clones was used. The first clone, designated YACG 35, was selected in the laboratory of Dr. H. H. Ropers from a genomic library (Müller et al. 1983) which had been established from DNA of human Y chromo- 
somes in the vector system $\lambda$ gt WES $\lambda B$ (Leder et al. 1977). The $Y$ chromosomes had been purified from chromosomes isolated from a Chinese hamster $X$ human hybrid line CH-Y-VII (Cremer et al. 1982), using the recently developed technique of dual beam sorting (Dean and Pinkel 1978; Dean 1980).

Clone YACG 35 contains a $6 \mathrm{~kb}$ human Eco RI insert consisting of a low copy sequence and adjacent repetitive sequences (Müller et al. 1983). Southern blot analysis (Southern 1975), using DNA from different cell strains indicated that the $6 \mathrm{~kb}$ fragment was located predominantly on the sex chromosomes.

The second clone, named " 2.8 " was selected from another genomic library (Cooke et al. in preparation) which had been constructed from $Y$ chromosomes purified by the method of single beam fluorescence activated sorting (Horan and Wheeless 1979; Krumlauf et al. 1982). In this case, chromosomes isolated from human lymphocytes of normal male karyotype were used for sorting (Fantes et al. 1983).

The human insert of clone 2.8 consists of two Eco RI fragments of $8 \mathrm{~kb}$ and $1 \mathrm{~kb}$ length respectively. The $8 \mathrm{~kb}$ fragment contains a repeated sequence with a relatively low copy number, the other fragment is present in one copy per haploid genome.

Nick translation. For use for in situ hybridization experiments, recombinant lambda DNA was labelled to high specific activity by nick-translation (Kunkel et al. 1979) with ${ }^{3} \mathrm{H}-\mathrm{dTTP}(100 \mathrm{Ci} /$ mmol; New England Nuclear Co.; $1 \mathrm{Ci}=3.7 \times 10^{10}$ becquerels). The ${ }^{3} \mathrm{H}$-labelled thymidine was present at a concentration of $20 \mu M$ in $20 \mu 1$ reaction mixture, containing $200 \mu M \mathrm{dATP}$, dCTP and dGTP, $10 \mathrm{~m} M$ Tris-HCl (pH 7.8), $50 \mathrm{~m} M$ NaCl, $10 \mathrm{mM} \mathrm{MgCl}, 5 \mathrm{~m} M$ 2-mercaptoethanol, plus $500 \mathrm{ng}$ recombinant lambda DNA, 50 pg DNase I and 5-10 units of DNA polymerase I. Incubation was carried out at $13^{\circ} \mathrm{C}$ for $2 \mathrm{~h}$, and unpolymerized nucleotides were removed by gel filtration over Sephadex G-50. DNA was ${ }^{3} \mathrm{H}$-labelled to specific activities of about $10^{7} \mathrm{cpm} / \mu \mathrm{g}$ of DNA.

In situ hybridization and autoradiography. In situ hybridization of molecular probes to metaphase chromosomes was carried out essentially as described by Gerhard et al. (1981). The chromosome preparations were treated with $70 \%$ formamide/ $2 \times \mathrm{SSC}$ at $70^{\circ} \mathrm{C}$ for $2 \mathrm{~min}$, then dehydrated with ethanol. In all cases the nick-translated lambda-DNA was denaturated for 5 min at $100^{\circ} \mathrm{C}$ before hybridization.

Hybridization reaction mixtures contained the ${ }^{3} \mathrm{H}$-labelled DNA probe at approximately $1 \mu \mathrm{g} / \mathrm{ml}$ in $50 \%$ formamide, $2 \times \mathrm{SSC}, 1 \times$ Denhardt solution (Denhardt 1966), $200 \mu \mathrm{g}$ salmon sperm carrier DNA per ml, and 10\% dextransulfate (Wahl et al. 1979). A $20 \mu$ aliquot of hybridization mix was applied to each chromosome preparation slide, covered with siliconized cover glasses and sealed with rubber cement.

Hybridization was carried out at $40^{\circ} \mathrm{C}$ for $16-18 \mathrm{~h}$ in a closed Petri dish. After hybridization, slides were washed four times for $20 \mathrm{~min}$ each in $2 \times \mathrm{SSC}$ at $65-68^{\circ} \mathrm{C}$, followed by two washes (20 min each) in $0.1 \times$ SSC at room temperature. Washed slides were dehydrated in ethanol and air dried. Then the slides were dipped in Ilford L4 photographic emulsion (1:1 with distilled water), air dried, and exposed for $2-4$ weeks at $4^{\circ} \mathrm{C}$ in a lightproof box. Exposed slides were developed in Ilford ID 19 developer (diluted $1: 1$ ) for $7 \mathrm{~min}$, fixed, rinsed in water and air dried.

Chromosome identification. Autoradiographs were stained with quinacrin mustard (Sigma). Metaphase spreads were photo- graphed using a Zeiss photomicroscope equipped with epifluorescence illumination. In addition, phase contrast pictures were taken.

In all cases the $Y$ chromosome was easily identified by its characteristic fluorescence pattern (Zech 1969). The X chromosome could be identified unequivocally in some experiments while this was not possible in others. In two experiments the method applied did allow identification of all chromosomes.

Quantitative evaluation of autoradiographs. Silver grains were counted a) on all chromosomes of the metaphase spread; b) on the $\mathrm{Y}$; c) on the $\mathrm{X}$. In two experiments, silver grains were assigned also to individual autosomes.

Due to the low grain densities (one to five silver grains per metaphase spread), every grain could be ascribed to a statistically independent event. This allows us to make the binomial assumption, and to determine the confidence limits $P_{1} \leqq P \leqq P_{2}$ for proportions where $P=$ (total number of grains observed on the chromosomes or chromosomal subregion under consideration)/(total number of grains on all chromosomes) and $P_{1}$ and $P_{2}$ the lower and upper limit of the $99 \%$ confidence level.

\section{Results}

Table 1 gives a survey of the in situ hybridization experiments performed with the two DNA probes YACG 35 and 2.8. All grains situated on chromosomes were counted, i.e. grains due to background and due to specific hybridization of the probes. In all experiments the percentage of silver grains on the human $\mathrm{Y}$ was observed to exceed background level (see below).

The DNA of the human Y has been estimated to represent about $1 \%$ of the DNA of the genome of cells of normal $46, \mathrm{XY}$ karyotype (Gray et al. 1979) and of cells of the Chinese hamster $\times$ human hybrid line used (Cremer et al. 1982). In the case of a random distribution of the silver grains, one should expect that only about $1 \%$ of the total number of silver grains should be located on the $\mathrm{Y}$ chromosome.

In all experiments the number of silver grains over the $Y$ exceeded the number of grains expected at random at the $99 \%$ confidence level. This indicates a highly significant binding of clones 2.8 and YACG 35 to the Y chromosome. Furthermore, a highly significant binding was also observed to the $\mathrm{X}$ chromosome in all experiments where the $X$ could be identified unequivocally. To achieve a more detailed assignment of the probes to particular regions of the human chromosomes, different cell types were used to confirm the chromosomal localization.

In case of clone 2.8 the silver grains were observed in all experiments to be situated in the following regions: Xq1.1, $\mathrm{Xp2.2,} \mathrm{Yp1.1} \mathrm{and} \mathrm{Yq1.2} \mathrm{(distal} \mathrm{end).-DNA} \mathrm{from} \mathrm{clone}$ YACG 35 was observed to hybridize to the same X chromosomal subregions as clone 2.8. On the Y chromosome, however, only one binding site was found which was located on the long arm in the border region between euchromatin and heterochromatin. In two experiments with cells of human male origin it was possible to identify all chromosomes in the autoradiographs, and the accumulation of grains on each chromosome of 22 metaphase spreads (in the case of clone YACG 35) and 17 metaphase spreads (in the case of clone 2.8), respectively, were evaluated.

In case of clone 2.8 a statistically significant autosomal binding site was found on the short arm of chromosome 3 
Table 1. In situ hybridization of clones 2.8 and YACG 35: Quantitative evaluation. For characterization of hamster $\times$ human hybrid cell line $\mathrm{CH}-\mathrm{Y}$-VII and mouse $\times$ human hybrid cell line $445 \times 393$ see Material and methods. For calculation of significance, the relative DNA content for $\mathrm{X}$ and $\mathrm{Y}$ chromosome (DNA content of $\mathrm{X}(\mathrm{Y}) / \mathrm{DNA}$ content of all chromosomes of the complement) was obtained as given in Material and methods. In case of hybridization to human cells the values of Gray et al. (1979) were used. For the CH-Y-VII cells, the relative DNA content of the $Y$ was established by dual beam flow cytometry (Cremer et al. 1982). For the $443 \times 393$ cells, the relative DNA contents were assumed for $\mathrm{X}$ and $\mathrm{Y}$ as in normal human cells. Since these chromosomes are deleted and since the average number of chromosomes in the $443 \times 393$ complement is 64 , the true relative DNA contents are somewhat lower

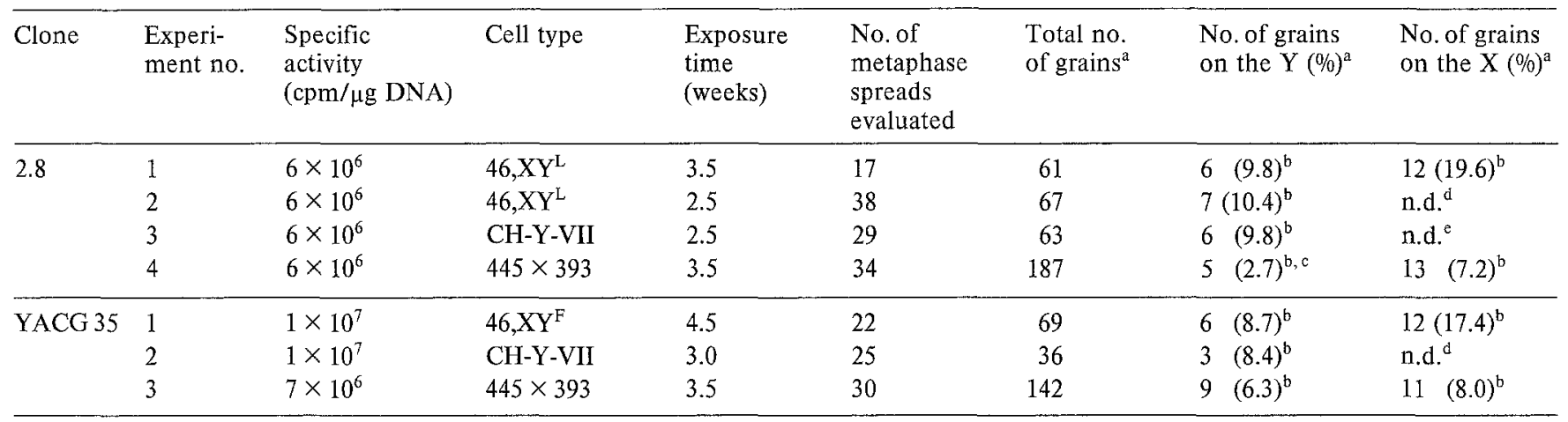

L: lymphocytes; F: fibroblasts

n.d.: not determined because of difficulties of identification of the X-chromosome in part of the metaphase spreads

Experiment number refers to independent in situ hybridization experiments. In experiment 1 with clone 2.8 , spreads of prometaphasic chromosomes (Müller and Schempp 1982) were used.

a Figures given are without correction for background

$b$ The number of silver grains observed over the X or Y chromosome as a whole is significantly non-random at the $99 \%$ confidence level

c For statistical evaluation it was taken into account that the translocated part of $Y q$ on the $X$ is considerably smaller $\left(\mathrm{ca} .1 / 3^{-1 / 2}\right)$ than the whole Y-chromosome

d Only the Y was clearly identified in all metaphase spreads

- Only the $\mathrm{Y}$ was clearly identified in all metaphase spreads while this was not possible for the Xp fragment translocated to a hamster chromosome (Müller et al. 1983)

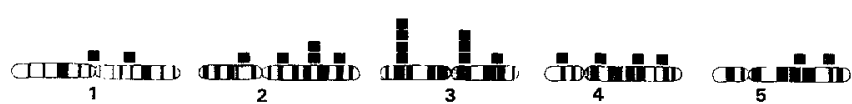

(1)

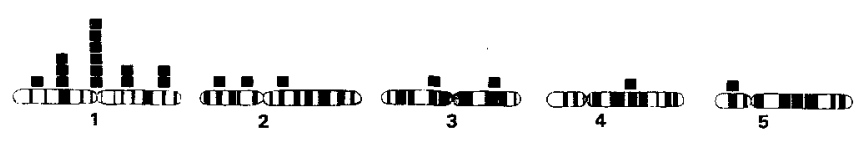

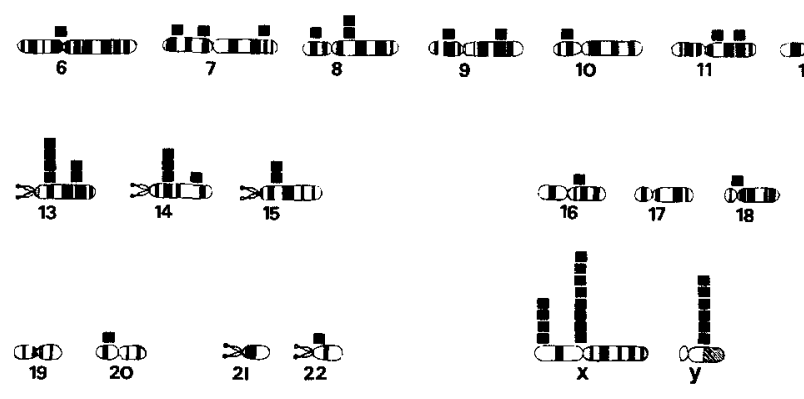

Fig. 2. In situ hybridization of DNA from clone YACG 35 to metaphase spreads of male human fibroblasts $(46, X Y)$ : Shown are the grain numbers accumulated from the evaluation of 22 metaphase spreads (Experiment 1 with clone YACG 35, see Table 1). For details, see legend to Fig. 1

\section{Discussion}

The chromosomal localizations of two cloned human sequences have been determined by in situ hybridization of ${ }^{3} \mathrm{H}$-nick translated DNA to spreads of mitotic chromosomes and quantitative evaluation of autoradiographs. The clones had been selected from two genomic libraries strongly enriched for human Y chromosomal sequences (Müller et al. 1983; Cooke et al. 1983).

For both sequences, several major binding sites were observed on human $\mathrm{X}$ and $\mathrm{Y}$ chromosomes while minor autosomal bindings could be assigned to chromosome No.1 (clone YACG 35) and No. 3 (clone 2.8), respectively. (3q2.4). DNA from clone YACG 35 hybridized significantly to the centromeric region of chromosome 1 , while no binding was observed on chromosome 3 . It is possible that other minor autosomal binding sites do exist which were not revealed due to the relatively low grain number. It may be concluded, however, that the human inserts of clones YACG 35 and 2.8 have their major binding sites and thus are located predominantly on the human sex chromosomes. 
While both sequences were observed to hybridize to the same $\mathrm{X}$ chromosomal subregions (centromere and distal part of short arm: Xp2.2) the Y chromosomal binding sites were clearly different: DNA of clone 2.8 hybridized to the distal regions of both arms of the Y; DNA of clone YACG 35 hybridized only to one $Y$ chromosomal site, namely the border region between $Y q 1.1$ and $Y q 1.2$.

It is concluded that the human inserts of these two independently derived clones are not identical. This conclusion is supported by the observation that the Eco RI restriction fragment lengths of the two inserts are also different.

To our knowledge, the two sequences described in this paper are the first ones with repetitive segments which are located on both $\mathrm{X}$ and $\mathrm{Y}$ chromosome and do possess major binding sites at the distal end of the short arm of the $\mathrm{X}$ chromosome. This segment is of considerable interest because in this region, a reduction of $\mathrm{X}$ inactivation has been observed (Mohandas et al. 1979; Müller et al. 1980; Migeon et al. 1982). Furthermore, this region is thought to be involved in crossover events with the distal end of the short arm of the $\mathrm{Y}$ chromosome (de la Chapelle 1981; Polani 1982; Burgoyne 1982). The hypothesis that the distal ends of the short arms of $\mathrm{X}$ and $\mathrm{Y}$ are homologous on the molecular level has recently received additional experimental support (Goodfellow and Tippett 1981; Goodfellow et al. 1983). If so, in general, to any sequence located on Xp22.3 a homologous sequence on Yp1.1 should exist and vice versa.

The construction of genomic libraries of the Y chromosome has made it possible to submit this assumption to direct testing. One of the sequences described in this paper (clone 2.8) would fit into this scheme; the other sequence (clone YACG 35) hybridized to different sites on $X$ and $Y$ which are not homologous to each other as defined by normal meiotic pairing.

One explanation for this surprising result might be a pericentric inversion of the $Y$ chromosome in the cells used. Such a pericentric inversion, however, is excluded because a cytogenetic examination revealed $\mathrm{Y}$ chromosomes with a normal G-banding pattern, and the same hamster $\mathrm{X}$ human hybrid line (CH-Y-VII) was used for assignment both of clones 2.8 and YACG 35.

Data for clone 2.8 show that at the molecular level the distal end of the short arm of the $X$ and the short arm of the $Y$ do indeed contain homologous sequences. The assignment of the insert of clone YACG 35, however, indicates that differences also do occur.

Obviously these differences are considerably larger than single base exchanges because such small differences would have gone unnoticed. For a number of autosomal pairs of chromosomes it is known that they may differ somewhat in DNA content and composition (Young et al. 1981; Langlois et al. 1982) and that this does not prevent normal meiotic pairing. Therefore, such a difference may also apply to the sex chromosomes. A detailed comparison of clones from genomic libraries of the $\mathrm{Y}$ chromosome with those of the $\mathrm{X}$ chromosome (Davies et al. 1981; Kunkel et al. 1982) will further enhance the possibility of elucidating in detail the homologies and the differences between the pairing regions of the human sex chromosomes on the level of DNA.

Acknowledgement. We thank our colleagues Dr. C. R. Müller, Dr. H. H. Ropers and Dr. T. Wienker in Freiburg for support and stimulating discussions, Dr.W. Schempp for preparations of spreads with chromosomes in prometaphase and Dr. H. D. Hager for valuable technical advice. In particular we thank Dr. W. Hennig (Nijmegen) in whose lab G.R. has received training in the technique of in situ hybridization. The mouse $\times$ human hybrid line (" $445 \times 393$ ") was kindly provided by Dr. H. H. Ropers.

This work was supported by the Deutsche Forschungsgemeinschaft (DFG) and by the Medical Research Council (MRC).

Parts of this investigation will be presented in a doctoral thesis (G.R.) to be submitted to the Faculty of Biology of the University of Heidelberg.

\section{References}

Burgoyne PS (1982) Genetic homology and crossing over in the $\mathrm{X}$ and $Y$ chromosomes of mammals. Hum Genet $61: 85-90$

de la Chapelle A (1981) The etiology of maleness in XX man. Hum Genet $58: 105-116$

Cremer C, Gray JW, Ropers HH (1982) Flow cytometric characterization of a Chinese hamster $\times$ man hybrid cell line retaining the human $Y$ chromosome. Hum Genet 60:262-266

Daiger SP, Wilden RS, Su TS (1982) Sequences on the human $Y$ chromosome homologous to the autosomal gene for argininosuccinate synthetase. Nature $298: 682-684$

Davies KE, Young BD, Elles RG, Hill ME, Williamson R (1981) Cloning of a representative genomic library of the human $X$ chromosome after sorting by flow cytometry. Nature $293: 374-$ 376

Dean PN (1980) Dual beam sorting at Livermore. In: Laerum OD, Lindmo T, Thorud E (eds) Flow cytometry IV. Universitetsforlaget, Bergen-Oslo-Trömsö, pp 41-44

Dean PN, Pinkel D (1978) High resolution dual laser flow cytometry. J Histochem Cytochem 26:622-627

Denhardt DT (1966) A membrane-filter technique for the detection of complementary DNA. Biochem Biophys Res Commun 23: 641-646

Fantes J, Green DK, Cooke HJ (1983) Purifying human Y chromosomes by flow cytometry and sorting. Cytometry $4: 88-91$

Gerhard PS, Kawasaki ES, Bancroft FC, Szabo P (1981) Localization of a unique gene by direct hybridization in situ. Proc Natl Acad Sci USA $78: 3755-3760$

Goodfellow PN, Tippett P (1981) A human quantitative polymorphism related to $\mathrm{Xg}$ blood groups. Nature $289: 404-405$

Goodfellow P, Banting G, Sheer D, Ropers HH, Caine A, FergusonSmith MA, Povey S, Voss R (1983) Genetic evidence that a Ylinked gene in man is homologous to a gene on the $\mathrm{X}$ chromosome. Nature $302: 346-349$

Gray JW, Langlois RG, Carrano AV, Burkhart-Schultz KJ, van Dilla MA (1979) High resolution chromosome analysis: One and two parameter flow cytometry. Chromosoma $73: 9-27$

Haldane JBS (1936) A search for incomplete sex-linkage in man. Annals of Eugenics $7: 28-57$

Horan PK, Wheeless Jr LL (1977) Quantitative single cell analysis and sorting. Science $198: 149-157$

Krumlauf R, Jeanpierre M, Young BD (1982) Construction and characterization of genomic libraries from specific human chromosomes. Proc Natl Acad Sci USA 79 :2971-2974

Kunkel LM, Smith KD, Boyer SH (1979) Organization and heterogeneity of sequences within a repeating unit of human $\mathrm{Y}$ chromosome desoxyribonucleic acid. Biochemistry $18: 3343-3353$

Kunkel LM, Tantravahi U, Eisenhard M, Latt S (1982) Regional localization on the human X chromosome of DNA segments cloned from flow sorted chromosomes. Nucleic Acid Res 10:1557-1578

Langlois RG, Yu LC, Gray JW, Carrano AV (1982) Quantitative karyotyping of human chromosomes by dual beam flow cytometry. Proc Natl Acad Sci USA 79:7876-7880

Leder P, Tiemeier D, Enquist L (1977) Ek2 derivatives of bacteriophage lambda useful in the cloning of DNA from higher organisms: The $\lambda \mathrm{gt}$ WES system. Science 196:175-177

Migeon BR, Shapiro LJ, Norum RA, Mohandas T, Axelman J, Dabora RL (1982) Differential expression of steroid sulphatase locus on active and inactive human X chromosome. Nature 299 : 838-840

Mohandas T, Shapiro LJ, Sparkes RS, Sparkes MC (1979) Regional assignment of the steroid sulfatase-X-linked ichthyosis locus: 
Implications for a non-inactivated region of the short arm of human X chromosome. Proc Natl Acad Sci USA 76:5779-5783

Moses MJ, Counce SJ, Paulson DF (1975) Synaptonemal complex complement of man in spreads of spermatocytes, with details of the sex chromosome pair. Science 187:363-365

Müller CR, Migl B, Traupe H, Ropers HH (1980) X-linked steroid sulfatase: Evidence for different gene-dosage in males and females. Hum Genet $54: 197-204$

Müller CR, Davies KE, Cremer C, Rappold G, Gray JW, Ropers HH (1983) Cloning of genomic sequences from the human $\mathrm{Y}$ chromosome after purification by dual beam flow sorting. Hum Genet $64: 110-115$

Müller U, Schempp W (1982) Homologous early replication patterns on the distal short arms of prometaphasic X and Y chromosomes. Hum Genet $60: 274-275$

Page D, de Martinville B, Barker D, Wyman A, White R, Francke U, Botstein D (1982) Single copy sequence hybridizes to polymorphic and homologous loci on human $\mathrm{X}$ and $\mathrm{Y}$ chromosome. Proc Natl Acad Sci USA $79: 5352-5356$

Pearson PL, Bobrow M (1970) Definitive evidence for the short arm of the $\mathrm{Y}$ chromosome associating with the $\mathrm{X}$ chromosome during meiosis in the human male. Nature 226:959-961
Polani $\mathrm{P}$ (1982) Pairing of $\mathrm{X}$ and $\mathrm{Y}$ chromosomes, non-inactivation of $\mathrm{X}$-linked genes, and the maleness factor. Hum Genet 60 : 207-211

Solari AJ (1980) Synaptonemal complexes and associated structures in microspread human spermatocytes. Chromosoma $81: 315-337$

Solari AJ, Tres LL (1970) The three-dimensional reconstruction of the $\mathrm{XY}$ chromosomal pair in human spermatocytes. J Cell Biol $45: 43-53$

Southern EMJ (1975) Detection of specific sequences among DNA fragments separated by gel electrophoresis. J Mol Biol 98 : 503-511

Wahl GM, Stern M, Stark GR (1979) Efficient transfer of large DNA fragments from agarose gels to diazobenzyloxymethyl-paper and rapid hybridization by using dextran sulfate. Proc Natl Acad Sci USA $76: 3683-3687$

Young BD, Ferguson-Smith MA, Sillar R, Boyd E (1981) High resolution analysis of human peripheral lymphocyte chromosomes by flow cytometry. Proc Natl Acad Sci USA 78 : 7727-7731

Zech L (1969) Investigation of metaphase chromosomes with DNAbinding fluorochromes. Exp Cell Res $58: 463$

Received July 21, 1983 / Revised September 12, 1983 